\title{
Multiple myeloma presenting as clival mass: a diagnostic dilemma
}

\author{
Pradeep Venkataswamy Reddy, ${ }^{1}$ Vikram Singh, ${ }^{1}$ Ravi Roy, ${ }^{2}$ Uday Yanamandra ${ }^{3}$
}

'Dept of Pathology, Army Hospital Research and Referral, New Delhi, Delhi, India ${ }^{2}$ Department of ENT and Head and Neck Surgery, Army Hospital Research and Referral, New Delhi, India ${ }^{3}$ Department of Clinical Haematology, Army Hospital Research and Referral, New Delhi, India

Correspondence to Dr Vikram Singh; vikram8165n@gmail.com

Accepted 22 February 2021

\section{DESCRIPTION}

Multiple myeloma (MM) is characterised by proliferation of clonal plasma cells. At presentation, extramedullary $\mathrm{MM}$ is found in approximately $7 \%$ of patients, whereas another $6 \%$ may develop extramedullary lesions later in their disease course. $^{12}$ Solitary plasmacytomas or multiple myeloma can present in the sellar and parasellar
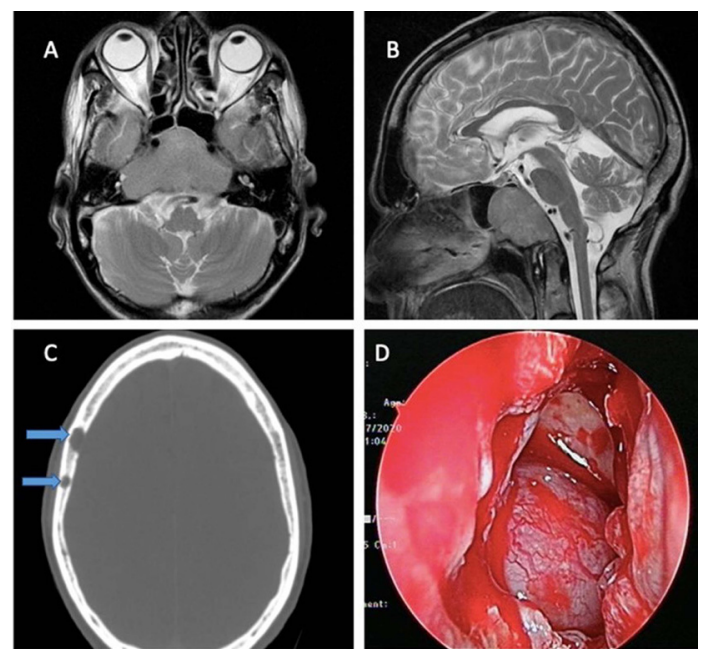

Figure 1 Radiological findings and per-operative finding. (A, B) MRI axial and sagittal views showing the extent of tumour, anteriorly occupying the sphenoid sinus with lateral extent into bilateral cavernous sinuses and invasion of bilateral petrous apex with complete involvement of the clivus. (C) Axial view bone window shows multiple lytic lesions in the right parietal bone (marked by blue arrows). (D) Endoscopic picture of the smooth lobulated vascular lesion in the sphenoid sinus. region in less than $1 \%$ of cases. ${ }^{3-5}$ Clival tumours are also extremely rare with an overall incidence of $0.1 \%-0.2 \%$ of all intracranial tumours, which predominantly includes clival chordoma and chondrosarcoma. We report an unusual presentation of multiple myeloma presenting as clival mass with neuro-ophthalmological involvement.

A 52-year-old man presented with complaints of diplopia in the left eye for 6 months, right hemicranial headache for 2 months and mucopurulent discharge from the right ear. He also had a history of hearing loss for 6 months. Examination revealed pallor, and left fourth and bilateral sixth cranial nerve palsies.

On evaluation at presentation, his haematological parameters were normal (haemoglobin, $145 \mathrm{~g} / \mathrm{L}$; total leucocyte count, $4.7 \times 10^{9} / \mathrm{L}$; platelet count, $\left.252 \times 10^{9} / \mathrm{L}\right)$. The biochemical parameters at presentation were blood urea nitrogen of $11 \mathrm{mg} / \mathrm{dL}$, serum creatinine of $0.24 \mathrm{mg} / \mathrm{dL}$ and corrected serum calcium of $9.6 \mathrm{mg} / \mathrm{dL}$. MRI of the brain and orbit revealed clival mass involving the left cavernous sinus measuring $5.8 \times 3.9 \times 3.1 \mathrm{~mm}$ and multiple lytic lesions of the skull (figure $1 \mathrm{~A}-\mathrm{C}$ ). Positron emission tomography with CT scan revealed fluorodeoxyglucose avid lesions in the clival region and skeleton (sternum and skull). Paraproteinaemia evaluation revealed light chain disease (serum protein electrophoresis: faint band in Kappa region, Kappa $(\kappa)=2320 \mathrm{mg} / \mathrm{L}$, Lambda $(\lambda)=21.3 \mathrm{mg} / \mathrm{L}$ with $\kappa / \lambda$ ratio of 108.92 , beta-2microglobulin $=2412 \mathrm{ng} / \mathrm{dL}$ ). Bone marrow examination revealed cellular marrow with no increase in plasma cells.
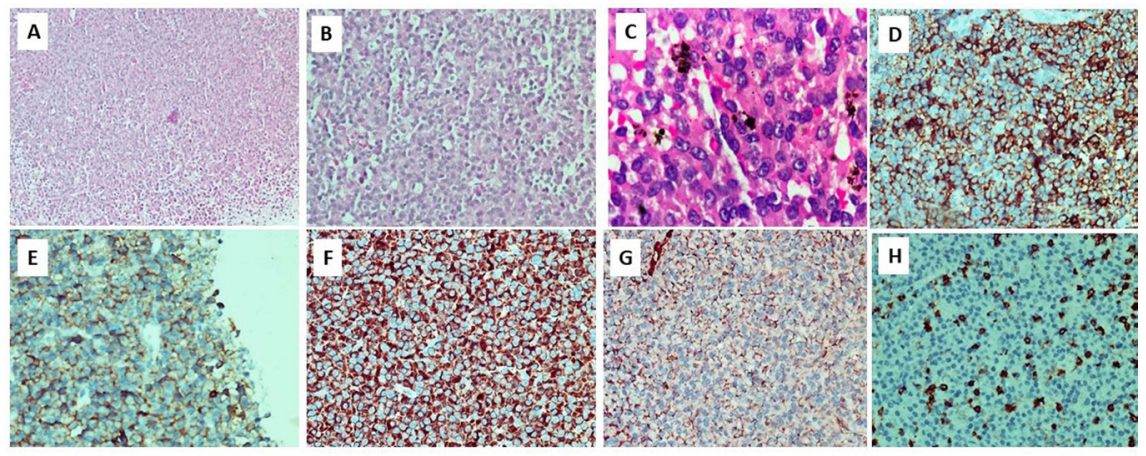

BMJ Publishing Group Limited 2021. No commercial re-use. See rights and permissions. Published by BMJ.

\begin{tabular}{|l|}
\hline To cite: \\
Venkataswamy Reddy P, \\
Singh V, Roy R, et al. BMJ \\
Case Rep 2021;14:e240670. \\
doi:10.1136/bcr-2020- \\
240670 \\
\hline
\end{tabular}

Figure 2 H\&E and immunohistochemistry (IHC) photomicrographs. (A, B) Section shows the presence of tumour arranged in sheet comprising mature-appearing plasma cells (H\&E stain, 20x). (C) Few immature plasma cells are also seen with high nucleus:cytoplasm ratio and conspicuous nucleoli (H\&E stain, 4020x). (D-H) Photomicrographs showing IHC results: tumour cells were positive for CD138 (D), CD38 (E) and Kappa (F) but negative for Lambda immunostain $(\mathrm{G})$, and Ki67 index was high, that is, $25 \%-30 \%(\mathrm{H})$. 
During transnasal endoscopic biopsy, he was found to have soft lobulated vascular mass occupying the sphenoid sinus with complete erosion of the clivus (figure 1D). Microscopic examination revealed mature and immature plasma cells in sheets (figure 2A,B). On immunohistochemical panel, these cells were positive for CD38, CD138 (figure 2C,D) and Kappa (figure 2E), and Lambda (figure 2F) immunostains showed Kappa restriction. Ki-67 index was 15\%-20\% (figure 2G). Tumour cells were negative for leucocyte common antigen, CD3, CD20, pancytokeratin and synaptophysin.

Based on these findings, the diagnosis of $\mathrm{MM}$ with clival plasmacytoma (C-R-A-B+) R-ISS III was made. The patient was treated with VCD chemotherapy (injection of bortezomib, injection of dexamethasone and injection of thalidomide daily) along with local palliative radiotherapy, and he is responding well.

\section{Learning points}

Extramedullary presentation of multiple myeloma as clival mass is rare.

- Radiologically and clinically, it can mimic other more common clival lesions.

- Tissue biopsy is important because plasma cell dyscrasias are fairly common, and biopsy may be required to differentiate plasmacytoma from any other clival tumours with incidental Monoclonal gammopathy of undetermined significance (MGUS).

- High index of suspicion and thorough haematological workup are required to reach the correct diagnosis.
MM presenting as clival mass can create a great diagnostic dilemma because these patients first come to ENT or neurosurgery OPDs. In a systemic review of 65 cases of sellar and clival plasmacytoma, 16\% had a history of known MM, whereas 37\% were diagnosed concurrently with MM presenting with parasellar plasmacytoma. ${ }^{6}$ High index of suspicion supported by an appropriate IHC panel is essential to arrive at the correct histological diagnosis, and then a multidisciplinary team approach is critical to achieve best therapeutic outcomes.

Contributors PVR, Pathology Resident, conceptualised and prepared the manuscript. VS, Pathologist, conceptualised and prepared the manuscript. RR, Treating ENT surgeon, supervised the manuscript. UY, Treating Physician, supervised the manuscript.

Funding The authors have not declared a specific grant for this research from any funding agency in the public, commercial or not-for-profit sectors.

Competing interests None declared.

Patient consent for publication Obtained.

Provenance and peer review Not commissioned; externally peer reviewed.

\section{REFERENCES}

1 Rajkumar SV. Multiple myeloma: 2016 update on diagnosis, risk-stratification, and management. Am J Hematol 2016;91:719-34.

2 Varettoni M, Corso A, Pica G, et al. Incidence, presenting features and outcome of extramedullary disease in multiple myeloma: a longitudinal study on 1003 consecutive patients. Ann Oncol 2010;21:325-30.

3 Clarke E. Cranial and intracranial myelomas. Brain 1954;77:61-81.

4 Bhartiya M, Pachisia A, Kapoor R, et al. Clivus and dural involvement in a case of multiple myeloma: a rare complication of multiple myeloma. Indian J Hematol Blood Transfus 2016:32:135-7.

5 Alshammari J, Monnier P, Daniel RT, et al. Clival chordoma with an atypical presentation: a case report. J Med Case Rep 2012;6:410.

6 Lee J, Kulubya E, Pressman BD, et al. Sellar and clival plasmacytomas: case series of 5 patients with systematic review of 65 published cases. Pituitary 2017;20:381-92.

Copyright 2021 BMJ Publishing Group. All rights reserved. For permission to reuse any of this content visit https://www.bmj.com/company/products-services/rights-and-licensing/permissions/

BMJ Case Report Fellows may re-use this article for personal use and teaching without any further permission.

Become a Fellow of BMJ Case Reports today and you can:

- Submit as many cases as you like

- Enjoy fast sympathetic peer review and rapid publication of accepted articles

- Access all the published articles

- Re-use any of the published material for personal use and teaching without further permission

Customer Service

If you have any further queries about your subscription, please contact our customer services team on +44 (0) 2071111105 or via email at support@bmj.com.

Visit casereports.bmj.com for more articles like this and to become a Fellow 